Pakistan Journal of Humanities and Social Sciences

July - December 2017, Volume 5, No. 2, Pages 104 - 114

\title{
Demand for New Provinces in Pakistan
}

\author{
Muhammad Mehran Latif ${ }^{1}$ \\ ${ }^{1}$ M. Phil. Scholar of Public Policy, PIDE School of Public Policy, Islamabad
}

\begin{abstract}
In this paper main objective is to discuss how demand of new provinces is important and what are best policies for government to resolve it? Ethno-lingual movements are rising for new provinces demand because at initial stage these demands were just for rights but with the passage of time changed due to political support. Also in this paper India's policy for new provinces is discussed to tell that why there are many provinces and less conflict. For Pakistan's new provinces advantages and disadvantages are briefly deliberated which can provide rationale to Pakistani government for making new provinces. At the end of paper a four tiers model for new provinces is elucidated, that model was used in Papua New Guinea. Pakistan by administration has same structure like Papua New Guinea. According to model there should be an independent commission or entity, Parliament and Ministries role for decision making. However, one day we have to make decision for new provinces either it is done earlier or later. Pakistan government should realign boundaries of all provinces with political consensus. An independent commission should form for new provinces which should frame basic criteria for current and new provinces for a permanent solution. Also it is recommended that a just principle in the form of a policy decision is the need of hour, taking on board all the parties, ensuring the division to satisfy the grievances of all stakeholders.

The role of higher education in the progress of a society is indispensable. It shapes up the minds, mold behaviors and develops distinctive capabilities in the human being to serve the society better. Higher Education in the Arab World began to emerge and spread after the mid-twentieth century. There is a dearth of empirical research pertinent to the employee performance in general and employee performance in higher education. This condition had therefore illuminated a significant gap in the education sector of KSA that tends to focus on overall sectoral problems and organizational level problems in respect to job performance. Thus, the present study may contribute to the existing literature on Public Sector Universities in KSA through proposed a research model which has not received much attention.
\end{abstract}




\section{Introduction}

Since creation of Pakistan, different political parties and civil-military governments govern it. Due to poor governance and policies a lot of issues and problems emerged in form of language, resource allocation, and low development, less representations in government, ethnicity and identity politics. Backwardness and ignoring from mainstream of priorities and policies, gave the pace to movements for new provinces. With the passage of time these movements which were for rights became political and ethnic based. After changing name of NWFP to KPK ethnicity increased and it provide a rationale to ethno-lingual movements. Mix demands for new provinces like areas division, resource distribution, ethnic and management based rose. In Pakistan some provinces are rich in natural resources like Baluchistan and KPK others have high population growth e.g. Punjab and Sindh. War on terror and poor governance of governments also creating a lot of problems for citizen of Pakistan. Cities with great development and good education are getting more jobs and backward areas people are not competing with them.

Although after $18^{\text {th }}$ amendment in constitution provinces are independent in resource using and budget allocation but still conflict on NFC award is existing. Punjab with large population (approximately 9 crore) are getting more share than all provinces from federal and bearing a lot of criticism. ${ }^{[1]}$ Other provinces are also trying for more shares with their individual claim. It is also observed with province independency and devolution, movements are re-emerged with pace which were before $18^{\text {th }}$ amendment. In next decades with growing population it would be necessary for Government to create more units for better governance and development. If we look around the world US with 50 states, India have more than 29 states and 8 union terrorities and China with 34 states are doing well economically and politically. ${ }^{[2]}$ It is also predicted, Pakistan will also perform well economically and politically if Provinces are divided in more units.

\section{A. Problem statement}

"Ethno-lingual and management based demand of new provinces is increasing in remote and backward areas for better resource allocation and development. It's necessary for Government to build a consensus for long term solution politically."

\section{Stakeholders}

- Federal and Provincial governments

- Political Parties

- Movement Leaders 
- General Public

- Media

Federal and provincial government can play a vital role in unanimity building over new provinces. According to constitution Federal government can approve bill from Parliament and after that concerned provincial government can approve it from Provincial Assembly. Government should involve movement leaders and other political parties for consultation, and then they can address the problem well. Also if needed Government can demand suggestions from journalists and general public .If someone is squandered from major stakeholders then they can create skirmish over process and consultation. So it is necessary for government to consult with major stakeholders for better and planned management of new provinces.

\section{B. Objectives}

- Major objective is to analyze what would be fruitful for new provinces either they should ethnic based or management.

- If division of provinces possible cans Governance, people's representations, seats quota, resources distribution will be sort out?

- What will be their impacts on national integrity and politics?

- To check division of provinces occurred in India and analysis in case of Pakistan.

\section{Background of the Research}

Pakistan has four provinces, one autonomous state, one capital terrority and one federally administrated area .For new provinces demand it is evident on this topic many researchers wrote in form of research articles as well as advise policies on newspaper's article. Basically movements emerged basically due to resource distribution. But with the passage of time due to awareness many voices raised from all over the Pakistan. So for this many authors wrote about there should no province on language or ethnic base. Many authors/researchers said that there should be division on new boundaries and no province on popular demand it should be on management base .In Pakistan there is diverse population and complex situation for division but researchers argue that it is necessary we should look towards the policies for new provinces of India and Afghanistan there is same situation like Pakistan but no conflict on new provinces.

In 28 January, 2013 a commission that was formed on new province of Saraiki from Punjab submitted its report. Senator Farhat Ulla Babar was chairman of commission. All 
members sent their personal notes to chairman but nothing happen after report. Becuase commission was formed after report approval from national assembly but Punjab assembly not approved this. In this situation academia perform its role well .They recommended various suggestions and proposal for new provinces .Also used some of their rationale base points for my policy paper. Some think tanks also conducted seminars and published reports on new provinces. Some of authors provide a good baseline and some authors just wrote on specific demand province. This is very hot topic; a sensible and good research can provide rationale to government for permanent peaceful environment of this country.

\section{Demands of Provinces from Pakistan}

\section{A. Demand of Hazara province from KPK}

After $18^{\text {th }}$ amendment ministries were devolved and resources control given to the provinces. Movements' leaders think that Hazara region is rich in mineral resources and it can earn through royalties on hydropower projects as well as from dams. Hindko is major language spoken in this region. After renaming NWFP to KPK (Khyber Pakhtunkhwa), provide a reason to inhabitants of Hazara for separate Province.

\section{B. Saraiki and Bahawalpur provinces Demand from Punjab}

At the time of independence Bahawalpur was an independent state and merged into Pakistan. Supporters of the Saraiki and Bahawalpur provinces expect that they will get more jobs on the base of quota from federal services. Due to disparity and low quality of education the candidates of southern Punjab are unable to compete with upper and central Punjab candidates. Punjab is getting more than 50\% quota in jobs from federal services that are why they are demanding separate province for more participation.

\section{Karachi/Urdu speaking province from Sindh}

Demand on language base is very sensitive and it will create more problems for government and will not opt this option easily. People of Karachi with the support of MQM (a political party) demanding their separate Urdu speaking province. It will be very crucial decision for government of Sindh and also people of Sindh it is possible that they may not accept this division.

\section{Pashtun Belt from Baluchistan}

Though the demand of separate province by Pashtun speaking people of the province is not on the table yet it could be heard in the future if new provinces were made elsewhere. 


\section{E. FATA (Federally Administrated Tribal Areas)}

It is demanded from all political leaders, parties and through media that FATA needed reforms for more development and political stability. With the passage of time packages were announced but result was not virtuous. After many decades it is announced now in current Government (2013-2018) that FATA will merge with KPK (Khyber Pakhtunkhwa) to streamline it. But still polemic in political parties on this issue either it would merge with KPK or to make it a separate province.

\section{India's Policy for New Provinces}

Post 1950, many nationalist movements demanding division of states on linguistic lines gathered momentum in the wake of which, in the winter of 1953, Prime Minister Jawaharlal Nehru appointed the States Reorganization Commission headed by the retired Chief Justice of the Supreme Court, Fazal Ali to reorganize the Indian states.

The commission submitted a report on September 30, 1955, recommending the reorganization of India's states and the report was debated in parliament. Finally, a bill amending the constitution, reorganizing the provinces into states and union territories called The States Reorganization Act was passed on 31 August 1956.

Initially, states were divided on the basis of languages after the state reorganization act of 1956 and Andhra Pradesh was first state to be carved out of the erstwhile Madras state followed by Gujrat and Maharashtra, division of Punjab into Haryana, Punjab and Himachal Pradesh. India's historical experience with state reorganization, in two main phases the mid1950 s and the late 1960s, has also been reassuring. While categorical evidence is not available, the general impression is that States that emerged from these reorganizations have done better. The experience of Himachal Pradesh, which today has emerged after Kerala as the exemplar in human development, is a good example of the possibilities and value of local experimentation, consequent to break-up of larger units. The only region that remained unaffected was the BIMARU States.

Madras Presidency was split, with the Kannada speaking parts merging with Mysore state, and Malayalam speaking areas merging with Travancore to form Kerala. By this time, south and west were effectively set and would not change since then. North and North East get altered.

In the 1960s-70s, the next major division occurred. Hindi speaking parts of Punjab was split to form Haryana in 1966, and the northern parts of Punjab became a full state - 
Himachal Pradesh in 1971.The Assam province of the North east was broken into 5 states Assam, Nagaland, Meghalaya, Mizoram and Arunachal Pradesh.

The second last division occurred in the 2000, when the states of Chhattisgarh, Uttaranchal and Jharkhand were created out of larger states. The most recent division Telangana from Andhra Pradesh but remember that India divided the states into more units on the base of culture, geography, linguistic and historic base ,but no state has been found on religious basis. The examples are,

- $\quad$ Geographic- Such as MP, UP

- $\quad$ Linguistic- Such as Southern India

- $\quad$ Cultural- Such as Telangana and Andhra

- $\quad$ Historic- Such as J\&K and Goa ${ }^{[10]}$

\section{A. Consensus over dual taxation in India}

To resolve the conflict of provinces with federal government recently in January, 2017 Indian center and states reach on a consensus over a dual control of GST (Goods and Services tax).They resolve it through wide consultation. According to consensus under the purposed tax regime $90 \%$ of all assesses with a turnover of Rs 1.5 crore or less will be assessed for scrutiny and audit by state authorities, the remaining $10 \%$ by the center .Above the limit, Centre and states will assess in a 50:50 ratio. The agreement hammered out was based on a proposal by Tamil Nadu (An Indian states).India will likely able to roll out the goods and services tax (GST) from $1^{\text {st }}$ of July 2017 following a breakthrough over the seemingly intractable issue of tax administration after the Centre accommodated states concerns.

\section{Policies for Pakistani government}

By seeing current situation of Pakistan and round the world Pakistan government should make provinces for development of areas and better control .There is needed for Government that they should make an independent commission which represent the members from all provinces and should set the new policies and recommendation with all possibilities and concerning major stake holders

Under the constitution article of 239 bill for provinces can be approved from parliament and compulsory from that province. In 2012 national assembly passed the bill for Saraiki province (South Punjab) but delayed by province Punjab assembly due to some reasons. If Government cannot manage they should divide areas for better management with the consultation of major stake holders, by keeping in mind what things can exploit national 
integrity? As for example India and Afghanistan made many provinces and India is comparatively performing well after division. It is responsibility of federal government to solve this issue with the consensus of all parties in a democratic way. Also focus on advantages and disadvantages and should make policies for their remedies.

\section{A. Advantages of New Provinces}

Pakistan will definitely grow faster. There are some points for favor of this argument.

- There will be efficient distribution of revenue all over the smaller provinces and there won't be an unfavorable balance of economic resources.

- Smaller provinces will resemble local government more and provincial government will be able to pay ample attention to the local glitches.

- More provinces will lead to more diverse set of policies and more opportunities for investors. This will encourage to industrial growth and prompt a competition for the province policies that attract the most investors. This will ultimately benefit the people.

- A smaller province will undeniably reflect the identity of the people better as larger provinces tend to have a more heterogeneous nature and its policies could be dominated by the most vocal communities or those societies that grab power.

- Administration will become more responsible and will be able to work proficiently. Police system will become more efficient as they will have less population under them to control.

- Indirect and direct tax collection will become efficient as Government would able to keep track of accomplishments around the states more efficiently.

- Health Care: It has been seen that the Capital cities of the provinces have one of the best infrastructure hospitals (e.g.: Mayo hospital Lahore, Lady Reading hospital Peshawar). Now if the new provinces are formed, they would try to build more good hospital, so that people from that province need not go to some other province for treatment. Thus, this will increase health care services in the province.

- More standardized schools, colleges and universities may be built by provincial government to satisfy their people.

- Accountable Government: People of the Province would be able to keep record of the development of the Provinces. Corruption will decrease and the ministers could be held accountable easily if they will play foul with the funds. 


\section{B. Disadvantages of New Provinces}

- There may be a lot of disputes over the boundaries of provinces. For example in India border disputes between Karnataka and Maharashtra that have not been resolved for decades! ${ }^{[13]}$

- Creation of new provinces will give rise to more and more factionalism and lead to the formation of local provincial parties that will care more for their own benefit rather than the nation as a whole. This will not generate a good effect with more factional parties demanding further segregation, until it goes out of hand.

- As now the state is divided, the natural resources and power plants would be divided too. Some provinces might get more resources as compared to other (E.g. KPK has hydral dams and mining mountains, as compared to Punjab and Sindh which has no dams) with less revenue, the development could be effected, as there would be less money for development.

- The Provinces would ask central government for money, but central government won't be able to allocate more funds because there will be lot of other provinces too who are in the same situation. Central has to give them too, thus there will be increasing burden on the funds.

- Creating a new Assemblies, High Courts and conducting elections for the new provinces will also be a burden on the central governments' funds.

\section{What should Government of Pakistan do?}

\section{A. Model for New Provinces}

A model was applied in "Papua New Guinea" (2009-2012) for creation of new provinces, which is a four tier process model. The same model can be applied in context of Pakistan for creation of new provinces.

This depicts the difficulties involved in the process, as it is very sensitive, and precautionary measures are indispensable. Government of Pakistan may put together proposals for administrative criteria and processes for Consideration on the creation of new provinces:

One option can be the establishment of new provinces either by amalgamation or separation between existing provinces or by the variation to existing Provincial Boundaries. In this background, a Four Tier Process Model may be proposed. 


\section{B. Basically it involves}

- The Initiator which may be a legislative body or some other entity which have to provide proposal that must determine how it recommends to encounter constitutional, legislative, ethnic, national policy, financial feasibility and geographical cohesion, popular backing and other

- Benchmarks.

- A proficient and independent Commission to monitor proposals evaluates applicable proposals, opine the legislature on those proposals and contribute in the flat processing.

- Parliamentary Committee with session to its associate institutions like Federal Ministry of Inter Provincial Coordination, Ministry of Finance, Ministry of Parliamentary Affairs and Establishment Division decide the final suitability of the proposal and familiarize legislation for boundary changes (including new provinces) if so then decided or some other decision may be taken.

- Parliament to decide on legislation for modification of borders.

In this Model there is a set of principles for the process which may be negotiated according to the native necessities. The principles for the procedure are,

i. To inaugurate a baseline set of chucks for establishing new provinces and boundary dissimilarities.

ii. To put the responsibility on Initiators of Proposals for new provinces/boundary dissimilarities to "make the case".

iii. To force initiators of proposals to make available sufficient information for wellversed decision making, especially costing and funding information.

iv. To give a coherent basis to the commission to make a decision on whether to commend introduction of legislation for a new province/boundary dissimilarities.

\section{Conclusion}

Federal government deals with all provinces and after $18^{\text {th }}$ amendment although many ministries shift to provinces but problem of law and order, development and especially health care not getting the right delivery from government either it is provincial or federal. To solve the problem of regions, language and less development it is necessary for government to make an independent commission and they have to make a report with consultation of stake holders how new provinces will approach. Whatever the finding they found government should try to make possible for betterment of people through legislation in parliament. If 
government will not consider the movements seriously then it is chance that everywhere it will convert to language or region base. There is need to build a consensus on new provinces. Pakistan with diverse culture and language need to handle carefully. It is a right time to do. After sometime if government try to make province on pressure of language base then it will creates a lot of problem. Now government can do it on administrative and political base .In short, the central Government thinks twice before dividing the state's such that it doesn't affect the economy of the state.

\section{Recommendations}

- Government should consider four tiers model.

- There is need to realign all provinces to minimize conflict.

- An independent commission for new provinces needed.

- By considering the diverse culture, new provinces matter is very sensitive and much more work needed before announcement.

- Government should ask entity, commission or committee to keep in focus language, region, culture, resources for new provinces in report. 


\section{References}

Ahmar, M. (2013). Conflict Prevention and the New Provincial Map of Pakistan. A Case Study of Hazara Province. University of Karachi, Journal of Political Studies, Vol. 20 Asghar, U.M. (2012).Demand of new provinces, ISSRA Papers.

Ibid.

Ibid

Chandio, K. (2015). Justification for more provinces. IPRI

Chaudhry, P.D. (2012).Creating new provinces in Pakistan: Print media analysis. Institute of peace and conflict studies. Retrieved http://www.ipcs.org/article/pakistan/creatingnew-provinces-in-pakistan-a-print-media-analysis-3581.html

GST: Centre, States reach consensus over dual control, rollout likely from July 1 .The $\begin{array}{llll}\text { Economic Times. (2017, January } & \text { 17). Retrieved }\end{array}$ http://economictimes.indiatimes.com/news/economy/policy/april-1-deadline-for-gstruled-out-4-options-now-for-arun-jaitley-in-budget 2017/articleshow/56598850.cms

Hafeez, M.M. (2014). Constitutional Framework for Formation of New Provinces in Pakistan. International Journal of Business, Economics and Law. Vol. 4, Issue 3 (June) ISSN 2289-1555.

Ibid.

Malik, A.R. (2017, March 4).The FATA Merger. The Nation. Retrieved http://nation.com.pk/columns/04-Mar-2017/the-fata-merger

Rasool, A.K. (2011, August 12).Do we need more provinces? The Express Tribune. Retrieved http://blogs.tribune.com.pk/story/7440/do-we-need-new-provinces/

Retrieved.https://www.quora.com/If-smaller-states-in-India-are-most-developed-isnt-itlogical-to-divide-Indian-States-further-What-are-the-complications-and-threatsinvolved\#

Soherwordi and Khattak, (2014).The creation of new provinces in Pakistan and its implication for and integrated country. J.R.S.P, Vol. 51.

What prompted the creation of various states within India? Retrieved https://www.quora.com/What-prompted-the-creation-of-various-states-within-India,

Ibid.

What prompted the creation of various states within India? Retrieved https://www.quora.com/What-prompted-the-creation-of-various-states-within-India 